picture. By demonstrating the practical utility of modern methods of rapid conveyance of news and equally by recording scientific developments wherever they occur, The Times has played a noteworthy part in the rapid progress of the past century.

\section{Rural Conditions in Roman Britain}

A Notable addition to our knowledge of the conditions of farm life in Roman Britain is made by the account of an excavation of farm buildings in Carnarvonshire carried out by $\mathrm{Mr}$. B. H. St. J. O'Neil on behalf of the Office of Works, which is described in the Times of December 29. The site is on Caerau farm, north of Pant Glas station, in an area which has already afforded evidence of similar cultivation sites, evidently parts of a rural group or community centring on the Roman fort of Segontium, at Carnarvon, and in which the ancient field system of terrace cultivation can still be readily discerned. Of a succession of four ancient farms along the hillside, facing the west, one is practically intact. Within what is described as an excellent system of ancient fields, rising one above another, are two separate courtyard houses, of which the first is an oval about $100 \mathrm{ft}$. Iong, bounded by a stone-faced wall of earth or turf. It was approached by a cobbled road $8 \mathrm{ft}$. wide, which passed through an opening in the wall into the courtyard. On this yard two rooms now open, but originally there were four. These rooms are circular, the larger having a diameter of $25 \mathrm{ft}$. Their structure is interesting. The walls are now $4 \mathrm{ft}$. high and may never have been higher. The roof was supported by six posts, for which the holes remain, mid-way between the wall and the centre of the building, where there may also have been a post. The room was provided with a stone bench on the west side, drains and a trench which may have been a slot to receive a wooden partition, dividing the room into two. The smaller hut, which also had a system of drains and gulleys, apparently was used for industrial purposes; the find of a crucible and two hearths suggests the reduction of metals. The second house on the edge of the field system has a polygonal boundary wall with a well-defined entrance and at least five rooms around the courtyard. One room appears to have had a ridge roof. The numerous pottery fragments are typical Romano-British of the second and third centuries A.D.

\section{The Vertebrate Evolutionary Tree}

For long we have accepted as well-established and equivalent the five classes of vertebrate animals, but recent zoological research, particularly on the palæontological side, has modified many old conceptions of relationship and suggests that there may be need for readjustment in the major groups. An attempt at a new classification which will give due weight to recent discoveries has been made by $\mathrm{G}$. Säve-Söderbergh (Arkiv. zoologi, 26, No. 17 ; 1934). Its main suggestions are that the present class Pisces is a medley of two of the three main stocks of Gnathostomes and parts of a third one. This third stock (Choanata) gave rise to the higher vertebrates, but probably by two routes, the ancestors of the Dipnoi leading to the Urodela, of the Crossopterygii to the Anura by a devious route. The Amphibia also must be looked upon as a mixed assemblage, which includes the two stocks just mentioned, but also an offshoot of the reptilian Reptiliomorpha, the Anthracosauria. Finally, birds and mammals belong to a richly branching part of the vertebrate phylogenetic tree, most of the branches being grouped as reptiles, while two equivalent branches are given unequal status as the independent classes Aves and Mammalia. The author regards it as absurd that equal systematic value should be given to these classes as to the fundamental group Pisces composed of two entire stocks of Gnathostome vertebrates, and half of the third stock. The writer's first reaction to this interest. ing and revolutionary view of vertebrate phylogeny, in which birds and mammals are grouped with reptiles and Anthracosauria as equal divisions of the Reptiliomorpha, is the thought that systematic classification is not entirely a matter of equivalents, and that even when phylogeny is known, weight must be given to outstanding novelties in evolution which have originated decisive lines of development. Thus the 'invention' of warm-bloodedness, which by adding to the adaptability of vertebrates has enabled them to conquer land surfaces far beyond the reptilian range, seems worthy, in association with the structures which made it possible, of a distinctive classificatory label.

\section{Starlings in London}

FOR some years, enormous numbers of starlings have taken to roosting on the ledges of buildings in central London, where they spend the winter nights in safety on such buildings as the National Gallery, Somerset House, St. Paul's and Covent Garden. In Edinburgh, similar hordes frequent the roof-ledges of the General Post Office and other buildings in the neighbourhood. The winter population of starlings in large towns must be unbelievably large, yet it appears still to be increasing. In the report for 1933 of the Committee on Bird Sanctuaries in Royal Parks (England), C. S. Bayne states that in 1933 (for the first time) starlings roosted on Duck Island in St. James's Park without an interval. In the first week of May, when winter roosts are usually deserted, he counted there eight thousand of them; but the numbers were greatest in autumn before the usual contingents moved in November to take up their winter quarters in Trafalgar Square. It is a matter of some interest to know whence come the starlings that flock to London at night, and R. W. Hale has discovered one of the sources. He has watched the birds feeding on and near Hendon Sewage Farm, and has seen them leave there in flocks about two hours before sunset. The flight of the flocks he has tapped at Cricklewood Lane, Finchley Road Station, Lord's and Baker Street Station. A line drawn through these points and extended passes through Trafalgar Square, so the slightest deviation from this would bring them over St. James's Park, and some of the largest flocks which settle in St. James's Park come from that quarter.

(Continued on p. 27.) 